\title{
Yerel Yönetimlerde E-Yönetişim Üzerine Bir Araştırma
}

\author{
A Research on E-Governance in Local Governments
}

\author{
Ramazan ŞENGÜL ${ }^{1}$ \\ Özlem BALIKÇI ${ }^{2}$
}

\author{
Araştırma Makalesi / Research Article \\ Geliş Tarihi / Received: 22.01.2021 \\ Kabul Tarihi / Accepted: 11. 05. 2021 \\ Doi: 10.48146/odusobiad.866733
}

Atıf /Citation: Şengül R., ve Balıkçı Ö., (2021), "Yerel Yönetimlerde E-Yönetişim Üzerine Bir Araștırma" ODÜSOBİAD 11(2), 417-436, Doi: 10.48146/odusobiad.866733

\begin{abstract}
Öz
Elektronik yönetişim veya ağ yönetişimi olarak da adlandırılan e-yönetişim, bilişim teknolojileri aracılığıyla, yönetime ilişkin birtakım bilgi ve hizmetlerin sosyal platformlara aktarılmasını ifade etmektedir. Günümüzde sanal yönetişim ağları, merkezi hükümet kadar yerel yönetimleri de ilgilendiren bir konudur. Yerel e-yönetişim uygulamalarından biri olarak ortaya çıkan e-belediyecilik ise yerel yönetimler tarafından bölge halkına sunulan hizmetlerin, elektronik araçlarla dijital ortamda gerçekleștirilmesidir. E-belediyecilik uygulamaları, eyönetişimin öngördüğü yönetim yapısını desteklediği ve içeriğini bu yönde geliştirdiği ölçüde işlevselliğini arttırmaktadır. Bu nedenle yerel yönetimlerin e-yönetişim unsurlarını ne derecede dikkate aldığını ve uygulamalarında bu unsurların ne kadarını karşıladığını tespit etmek önemlidir. Çalışmanın amacı, yerel yönetim politikalarının e-yönetişim parametreleri kapsamında ortaya konulmasıdır. Bu çalışmada, bahsi geçen hususları incelemek amacıyla, örneklem olarak Ege Bölgesi büyükşehir ve il belediyeleri seçilmiştir. Örnekleme dâhil belediyelerin resmi internet sitelerinin analizi kapsamında elde edilen bulgular, belediyelerin eyönetişimin öngördüğü unsurların çoğuna yer verdiğini göstermekle birlikte bu durumun belediyeler arasında farklılaştığını ve belediyelerin ilgili unsurlar konusunda yeterliliklerini arttıracak düzeyde gelişim göstermeleri gerektiğini ortaya koymaktadır.
\end{abstract}

Anahtar Kelimeler: Yerel Yönetimler, Dijital Dönüşüm, E-Yönetişim, E-Belediyecilik, Çevrimiçi Hizmet

\begin{abstract}
E-governance, also called electronic governance or network governance, refers to the transfer of certain information and services related to management to social platforms through information technologies. Nowadays, virtual governance network is a matter of interest that concerns local governments as much as the central government. E-municipality applications, which emerged as one of the local e-governance applications, are the realization of the services offered by local governments to region citizens in a digital environment with electronic tools. E-municipality practices increase their functionality to the extent that they support the management structure envisaged by e-governance and develop its content in this direction. For this reason, it is important to determine to what extent local governments take e-governance elements into consideration and to what extent these elements meet in their applications. The aim of the study is to reveal local government policies within the scope of e-governance parameters. In this study, Aegean Region metropolitan and provincial municipalities were selected as the sample in order to examine the mentioned issues. The findings obtained within the scope of the analysis of the official websites of the municipalities, including the sample, show that the municipalities include most of the elements envisaged by e-governance, but it also noted that this situation differs between municipalities and it shows that municipalities need to develop at a level to increase their competence in related elements.
\end{abstract}

Keywords: Local Governments, Digital Transformation, E-Governance, E-Municipality, Online Service

\section{Giriş}

Bilgi ve iletişim teknolojilerinde yaşanan gelişmeler ekonomik, siyasal, toplumsal pek çok alanda etkili olduğu gibi kamu yönetiminde de etkisini göstermektedir. Bilgi toplumuna dönüşüm ve beraberinde hızla artan dijitalleşme, çağın gereklerine ayak uydurmak durumunda olan yönetimin

\footnotetext{
1 Prof. Dr., Kocaeli Üniversitesi, İİBF Siyaset Bilimi ve Kamu Yönetimi Bölümü, ramazan.sengul@kocaeli.edu.tr, ORCID ID: 0000-0002-3164-9676

2 Sorumlu Yazar, Yüksek Lisans Öğrencisi, Kocaeli Üniversitesi, Sosyal Bilimler Enstitüsü, Yönetim Bilimleri Anabilim Dalı, ozlemm.balikci@gmail.com, ORCID ID: 0000-0002-5865-0394
} 
birtakım iş ve işlemlerinin sanal ağlara taşınmasını gerekli kılmaktadır. İçinde bulunduğumuz çağın dinamik yapısı, hantal, bürokratik, kapalı yönetim anlayıșını ve verimsiz yönetim kültürünü geride bıraktıracak nitelikte yeni yönetim modellerini gerektirmektedir. Yönetsel sorunlara bir çözüm niteliğinde ortaya çıkan yönetişim yaklaşımı, demokratik, katılımcı, iş birliğine dayalı, şeffaf, hesap verebilir yönetim anlayışı kurgulamaktadır.

Dijital dönüşümün kamu sektörüne yansıması ve kamusal hizmetlerin elektronik ortama taşınması fikri ve uygulamaları, e-demokrasi, e-katılım gibi pratikleri ve e-devlet, e-belediye gibi dijital yönetim uygulamalarını beraberinde getirmiştir. Amaçlarından biri de yönetişim yaklaşımını geliştirmek olan e-yönetişim ise e-devlet ve yönetişim kavramlarının ötesinde, devlet ile vatandaş etkileşiminin ön planda tutulduğu, demokratik ve katılımcı yönetime uygun zemini yaratan ve bilişim teknolojilerinden de en iyi şekilde faydalanan ağ yönetişimidir (Parlak ve Doğan, 2019). E-yönetişim uygulamalarının, halka en yakın hizmet sunan birimler olan yerel yönetimlere yansıması sonucunda, yerel topluluk ile yerel yönetimler arasında sürekli etkileşim, bilgi aktarımı ve görüş bildirimi, kaliteli, hızlı ve kesintisiz hizmet sunumu mümkün hale gelmiştir. Türkiye özelinde bakıldığında eyönetişimin yerel yönetimlere yansımasının en açık örneği e-belediyecilik uygulamalarıdır. Ebelediyecilik uygulamaları sayesinde yönetişim ve e-yönetişime ilişkin unsurların yerel yönetimlerde uygulanması ve yerel halkın istek ve şikâyetlerinden en hızlı şekilde haberdar olunması, 7/24 hizmet sunumu, zaman ve maliyet tasarrufu sağlanması mümkün olmaktadır.

Yerel yönetim politikalarının e-yönetişim parametreleri kapsamında incelendiği çalışmamız üç bölümden oluşmaktadır. İlk bölümde dijital dönüşüm ekseninde şekillenen kamu yönetimi anlayışı ve bunun sonucu ortaya çıkan e-yönetişim yaklaşımı ele alınmıştır. İkinci bölümde Türkiye'de eyönetişimin yerel düzeyde gelişimi ortaya konulmuştur. Üçüncü bölümde ise Ege Bölgesi büyükşehir ve il belediyeleri kapsamında yerel yönetimlerin e-yönetişim uygulamaları karşılaştırmalı olarak analiz edilmiş ve elde edilen bulgular değerlendirilmiştir.

\section{Kamu Yönetiminde Dijital Dönüşüm ve E-Yönetişim}

Uzun süre özel sektördeki kimi yönetim uygulama ve süreçlerini açıklamak için kullanılan "yönetişim", devlet yönetimi bağlamında ele alındığında kurumsal/anayasal sistemlerin sınırlı ve yanıltıcı olduğunu ileri sürerek, devletlerin geleneksel biçimsel anlayışlarına karşı çıkan bir yaklaşımdır (Stoker, 1998, 19). Bu yeni yaklaşım mevcut yönetim yapısında birtakım değişiklikleri de beraberinde getirmektedir. Yönetişim, birey ve devlet arasındaki münasebetin yeniden düzenlenmesinin kavramsal karşılı̆̆ı olarak kaynak ve yetkilerin tek elde toplandığı, katı hiyerarşiye sahip yönetim anlayıșından çok paydaşl, ağsal iletişime dayalı, devletin yönetici işlevinden çok yönlendirici ve destekleyici işlevinin ön planda olduğu, toplumsal işbirliğini esas alan yönetim anlayışına geçişi ifade etmektedir (Tekeli, 1996, s. 46).Öyle ki gerek sivil toplum kuruluşlarının gerekse özel sektörün, karar almadan denetime kadar yönetimin her aşamasına katılması, kendi kendini yöneten ilişki ağlarının oluşması ve yönetim sürecinde yer alan tüm aktörlerin uzun vadeli bir iş birliği ekseninde kendi kaynak ve becerilerini ortak çıkar ve kamu yararı doğrultusunda kullanması yönetişimin temelini oluşturmaktadır (Özer, 2017, 460).

Yönetişim, mekânsal ölçekte "küresel, ulusal ve yerel" olmak üzere üç farklı düzlemde ortaya çıkmaktadır (Kalkışım, 2019, 21). Bu üç türden birisi olan yerel yönetişim, yerelin gerek sosyal gerekse ekonomik geleceğine ilişkin kararlarının, yalnızca siyasi ve resmi kurumlar tarafından verilemeyeceğini, herhangi bir yerel alanın kaderini etkileyen siyasi süreçlerin içinde çok çeşitli aktörler bulunduğunu savunur (Goodwin ve Painter, 1996). İyi yönetişimden bahsedebilmek için ise vatandaşın karar alma süreçlerinde katılım ve temsilinin sağlanması, etkin bir sivil toplumun varlığı, hukukun üstünlügünü ilke edinmiş bir yönetim, güçlü yerel yönetim yapısı, yönetimde açıklık ve hesap verme sorumluluğunun sağlanmış olması, kaliteli hizmet sunumu, rekabet ve piyasa ekonomisi ile uyumlu alternatif hizmet sunum yöntemlerinin ve dünyada gerçekleșen dijital devrime uyumun mevcut olduğu siyasal ve ekonomik bir düzen gerekmektedir ( Henden ve Henden, 2005).

Dünyada gerçekleşen dijital devrim, çeşitli toplumsal ve endüstriyel süreçlerin sonucu olarak karşımıza çıkmaktadır. 18. yüzyılda İngiltere'de başlayan, el emeğinin yerini makine gücüne bıraktı̆̆ı Endüstri 1.0'dan sonra, telefonun icadı ve uzak pazarlara kolay erişimin sağlanması Endüstri 2.0'a zemin hazırlamış, bilgi teknolojilerinde yaşanan hızlı gelişmeler de Endüstri 3.0'ı beraberinde getirmiştir (Özen ve Gürel, 2020). Günümüz dünyasında ise ülkelerin, bireylerin, kurumların, nesnelerin ve daha birçok alanın işleyiş ve ilişkilerinde ( çalışma alışkanlıkları, değer yargıları vb.) 
köklü değişiklikler ve dijitalleşmeye hızlı bir geçiş görülmektedir (Güçoğlu, 2020, 618). Küresel ölçekte ve neredeyse her alanda yaşanan bu topyekûn dönüşümü açıklamakta, ilk olarak 2011 yılında Almanya Hannover Fuarı'nda gündeme gelen ve temelde "mobil internet ağları, küçük ve güçlü sensörler, yapay zekâ ve makine öğrenmesi" bileşenleri çevresinde karakterize edilen "Endüstri 4.0" terimi kullanılmaktadır (Güçoğlu, 2020, 618). Endüstri 4.0 ile beraber gelişen teknolojiler, çoğalan iletişim kanalları, hızla büyüyen bilgi paylaşım ağları; işletmeler başta olmak üzere ülkelerin ekonomisi üzerinde günden güne artan öneme sahiptir (Aygün ve Satı, 2020). Dijital çağın ürünü olan hızlı entegrasyon ve nesnelerin hızlı etkileşimi, işletmelerin gerek mali gerekse kurumsal verilerine anında ulaşmasına ve böylece hizmet alımından hizmet sunumuna dek, karar alma süreçlerini mümkün olan en kısa süre içerisinde tamamlamasına olanak sağlamaktadır (Özen ve Gürel, 2020). Başka bir deyişle dijital dönüşüm, işletmelerin;"iş modelleri, müşteri ilişkileri, iş tanımları, çalışan yetkinlikleri, iș kültürü" vb. tüm bileșenlerini dönüștürmekte, en kısa zamanda en yüksek verimi sağlamak amacıyla bilişim teknolojilerini iş süreçlerine entegre etmektedir. Yeni çağda, nesnelerin interneti; insandan bağımsız üretimi yaygınlaştırmakta, büyük veri havuzları; müşteri analizini kolaylaștırmakta, bulut bilişim; zaman ve yer aramaksızın veri paylaşımını mümkün kılmaktadır. ( Klein, 2020, 999-1002). Örneğin; sağlık sektöründe teknolojik nesneler ile bireysel sağlık verileri toplanabilmekte, bu veriler uluslararası veri tabanlarında ileride kullanılmak üzere saklanarak kişilere sağlıklı yaşam koçluğu hizmeti verilebilmektedir. Tarım sektöründe ise topraktaki nem ve havadaki sıcaklık gibi veriler ile çalışan sulama sistemleri mevcuttur. Bir başka örnek olarak eğitim sektöründe kullanılan akıllı sınıf ve öğrenci takip aplikasyonları gösterilebilir (Çark, 2020, 1255). Özel sektör ve müşteri özelinde düşünüldügünde ise dijital dönüşümün alışveriş alışkanlıkları üzerinde de çeşitli etkiler yarattığı görülmektedir. Çoğu verinin internet üzerinde kolayca toplanması, veri havuzuna erişimin kolaylaşması ve yatay etkileşim yoluyla tarafların online iletişim ağları sayesinde buluşması, alışverişi de ağ yapısal sistemlere taşımakta, e-ticaret, e-girişim, ealışveriş gibi alanları yaygınlaştırmaktadır. Hayatın her alanında yaşanan bu dönüşümün medya üzerindeki yansımaları da sosyal medyanın güçlenmesiyle sonuçlanmakta, iletişim her zamankinden daha hızlı bir hal alırken, bireylerin, örgütlerin, aktivistlerin, sivil toplum kuruluşlarının ve daha birçok aktörün seslerini ve taleplerini duyurması kolaylaşmaktadır (Güçoğlu, 2020, 619).

Dünyada yaşanan değişim ve dönüşümler pek çok alanda etkili olduğu gibi kamu yönetiminde de etkisini hissettirmektedir. Özel sektörde, e-ticaretin yaygınlaşması; kitle iletişiminde, alternatif medya olarak görülen sosyal medyanın gücünün artması gibi gelişmeler yaşanırken kamu sektöründe de vatandaş ve kamu kurumları arasında etkileşimin artması, kamusal hizmetlerin internet ve internet tabanlı çeşitli uygulamalar üzerinden verilmeye başlanması yeni yönetim dinamiklerinin bir parçasını oluşturmaktadır (Güçoğlu, 2020, 619). Bu durum, kamu idarelerinin ağa bağlı ve açı bir hükümet biçimine dönüştürülmesinin önünü açmakta, kamusal değer yaratmak ve toplumsal zorlukları ele almak için dijital teknolojilerden en iyi şekilde yararlanarak, geleneksel yönetimden, açık yönetim platformlarını kapsayan dijital yönetime geçişi hızlandırmaktadır (Lindgren ve Veenstra, 2018).

"Akıllı yönetişim" ve "e-yönetişim" olarak adlandırılan ve kamusal hizmet sunumunda keskin bir değişimi gerektiren dijital dönüşüm sürecinin etkisindeki yeni yönetim anlayışı, özellikle 21. yüzyll hükümetleri için oldukça önemlidir (Henden ve Henden, 2005). "Elektronik yönetişim" anlamına gelen "e-yönetişim", en genel anlamıyla, yönetişimi geliştirmek amacıyla hükümetin ve kamu sektörünün çeşitli düzeylerinde bilgi ve iletişim teknolojilerinin (BİT) kullanılması olarak ifade edilmektedir ( Sexana, 2005; Palvia ve Sharma, 2007; Dawes, 2008 ; Bannister ve Connoly, 2012 ; Ekşi, 2019; Uzun, 2019).

Uygun teknolojilerin kullanımı yoluyla e-yönetişim; demokrasiyi güçlendirme, bireysel özerkliği arttırma, hizmetlerin adil ve verimli sunumunu teşvik etme sorumluluğunu üstlenmektedir (Sexana, 2005; Doğan ve Ustakara, 2013). Bu sorumluluğun yerine getirilmesi, bir ağ yönetişimi olarak da adlandırılabilecek e-yönetişimin;

- Müzakere yoluyla bireylerin aktif katılımını sağlaması ve yaratıcı fikirler için alan yaratması (Newman, 2004, 20);

- Mevcut bilgi kanallarını dijitalleștirerek, gerek kurumlar gerek kişiler gerekse kurumlar ile kişiler arasındaki ilişskileri daha açık ve yatay düzlemde koordine etmesi (Heeks, 2001, 2);

- Kamu hizmetlerinin düşük maliyetle yüksek kalitede sunulabilmesini sağlaması (Dawes, 2008 , 8) gibi yapısal özellikleri sayesinde mümkün görünmektedir. 
Bilgi toplumunun ürettiği bir kavram olan e-yönetişimin (Sayımer, Dondurucu ve Küçüksaraç, 2019) aynı zamanda demokratik yönetişimi beraberinde getirdiğini (Uzun, 2019, 40) ve bunun sonucunda, edemokrasi, e-devlet, e-iş (Demirel, 2010, 70), e-katılım, e-oylama gibi kavramların e-yönetişimle ilişkilendirilebileceğini söylemek mümkündür (Uzun, 2019, 40).

E- yönetişim kapsamında, merkezi yönetime kıyasla vatandaşa daha yakın olan yerel yönetimlerin, hizmetlerinde daha erişilebilir olması, yerel demokrasinin yenilenmesine katkıda bulunması, modern iletişim altyapısı ve e-iş çevresinin etkin tanıtımı ile yerel ekonomiyi canlandırması ve tüm bunlar için bilgi toplumu gelişimini titizlikle desteklemesi beklenmektedir (Trajkovık, 2013, 22). Eyönetişim yaklaşımıyla ortaya çıkan uygulamalardan biri olan e-belediyecilik, belediyelerin yerel halka karşı gerçekleştirmekle yükümlü olduğu mal ve hizmet sunumunun, elektronik ortamda gerçekleștirildiği sosyal hizmet platformudur (Alodall, Tuncer, Usta ve Halis, 2012). Yerel e-yönetișim olarak da adlandırılan bu uygulamanın önemi, yerel yönetimlerin halka en yakın hizmet sunan ve yönetişim anlayışına en iyi uygulama alanı yaratan birimler olması noktasında ortaya çıkmaktadır (Belli ve Aydın, 2019). E-belediye ile amaçlanan, vatandaşların yönetime daha fazla ve kolay katılımının desteklenmesi, herkesin, her zaman bilgiye ulaşmasının sağlanması, zamandan tasarruf ederek verimliliğin yükseltilmesi ve böylece vatandaş memnuniyetinin arttırılmasıdır (Ünlü, 2016, 77). Edevlet hizmetlerinin bir uzantısı olan e-belediye hizmetleri; elektronik ortamın hızlı yapısı sayesinde yerel halkın talep ve şikâyetlerine daha çabuk ulaşabilmekte, beklenti ve çözümleri güvenilir yöntemler ile ve zamanında yerine getirebilmektedir (Yllmaz, 2019, 513). Bu sayede belediye ile yerel halk arasında kaliteli hizmet sunumunun ve yerel demokrasinin geliştirilmesi hedeflenmektedir (Hazman, 2005, 69).

\title{
Türkiye'de E-Yönetişimin Yerel Düzeyde Gelişimi
}

Türkiye'de e-yönetişimi hayata geçirmek amacıyla, geçmişten bugüne çeşitli girişimlerde bulunulmuştur. Bu girișimlerden en önemlileri, Türkiye'de e-dönüşümü öngören, e-Avrupa + Girișimi (2001), e-Dönüşüm Türkiye Projesi (2003) ve e-Devlet Kapısı Projesi'dir. Projelerin ortak amacı, bilgi toplumu stratejilerini hayata geçirmek yoluyla vatandaşlara daha kaliteli ve etkin hizmet sunumu gerçekleştirerek; katılımcı, şeffaf, basit iş süreçlerine sahip devlet yapısı oluşturmaktır (Demirel, 2010, 82-83). Türkiye'de e-yönetişim kapsamında gelişen e-Devlet konusu, farklı yasa ve yönetmeliklerde dağınık bir şekilde düzenlenmiştir. 2009 yılında, e-Devlet'i gerek mali gerek yönetsel ve gerekse personel açısından ele alacak temel kanun oluşturmak amacıyla "e-Devlet ve Bilgi Toplumu Kanun Tasarısı Taslağı” hazırlanmış, ancak kanunlaşma olanağı bulamamıştır (Kalkınma Bakanlığı, 2018). Günümüzde e-Devlet mevzuatı kapsamında en önemli yasal düzenleme, 2011 yılında çıkarılan 655 sayılı “Ulaştırma, Denizcilik ve Haberleşme Bakanlığı (UDHB)'nın Teşkilat ve Görevleri Hakkında Kanun Hükmünde Kararname"dir. Bu kararnamenin 2.maddesine göre;

\begin{abstract}
"e-Devlet hizmetlerinin kapsamı ve yürütülmesine ilişkin usul ve esasları belirlemek, bu hizmetlere ilişkin eylem planları yapmak, koordinasyon ve izleme faaliyetlerini yürütmek, gerekli düzenlemeleri yapmak ve bu kapsamda ilgili faaliyetleri koordine etmek görevi bu bakanliğa (UDHB) verilmiştir."
\end{abstract}

3 Eylül 2016 tarihinde Resmi Gazetede yayımlanarak yürürlüğe giren 29820 Sayll "e-Devlet Hizmetlerinin Yürütülmesine İlişkin Usul ve Esaslar Hakkında Yönetmelik” e-Devlet hakkında genel bilgilere, sunum ilkelerine, hizmet amaçlarına yer vermektedir.

Türkiye'de e-Devlet uygulamalarının yansıması olarak ortaya çıkan e-belediyecilik uygulamalarının gelişimine katkıda bulunan "yerelde elektronikleşme" kapsamında girişimler de çeşitli aşamalardan geçmiştir. Geçmişten günümüze kadar olan yerel e-yönetişim bağlamında yaşanan değișimler aşağıdaki görselde (Görsel 1), kronolojik olarak gösterilmiştir³.

\footnotetext{
${ }^{3}$ Görsel, Henden ve Henden (2005), Sayımer ve diğerleri (2019)'nin çalışmalarından ve https://www.yerelnet.org.tr/hakkimizda/, (Erişim Tarihi: 09.05.2020), https://www.belediye.gov.tr/hakkimizda (Erişim Tarihi: 11.05.2020) sitelerinden derlenen bilgilerden yararlanılarak hazırlanmıștır.
} 


\begin{tabular}{|c|c|}
\hline $\begin{array}{c}\text { PROJE/PLAN/UYGULAMA } \\
\text { ADI }\end{array}$ & AÇIKLAMASI \\
\hline Yerel-NET Projesi (2001) & $\begin{array}{l}2001 \text { yılında, Devlet Planlama Teşkilatı ve TODAİE - YYAEM } \\
\text { işbirliği ile hayata geçirilmiş, ülkedeki yerel yönetim } \\
\text { birimlerinin deneyimlerini ortak iletişim havuzunda } \\
\text { paylaşmaları düşüncesinden hareketle kurulmuştur. } 2018 \\
\text { Yllında } 703 \text { Sayılı KHK ile TODAİE'nin kapatılmasının ardından, } \\
\text { YerelNET internet sitesi de (www.yerelnet.org.tr )kapatılmıştır. } \\
\text { Mevcut internet sitesinde yer alan bilgilere göre, } 2020 \text { yılında } \\
\text { "kâr amacı gütmeyen bir grup eğitim sever tarafindan kurulan } \\
\text { Yerel Net Derneği ve YerelNET markaları" tarafından site aynı } \\
\text { bağlantı adresiyle tekrar açılmıştır. }\end{array}$ \\
\hline YERELBILGII Projesi (2001) & $\begin{array}{l}\text { Yerel Yönetimler Bilgi Tabanı Projesi, yerel yönetimlerle alakalı } \\
\text { verileri sanal düzlemde bir araya getirerek, bu verilerin politika } \\
\text { oluşturma ve karar alma sürecine fayda sağlayacak şekilde } \\
\text { derlenmesini amaçlamaktadır. Proje, Türkiye ve Orta Doğu } \\
\text { Amme İdaresi Enstitüsü (TODAİE) ile Yerel Yönetimler } \\
\text { Araştırma ve Eğitim Merkezi (YYAEM) tarafından hazırlanmış, } \\
2001 \text { yılında yürürlüğe girmiştir. }\end{array}$ \\
\hline $\begin{array}{l}\text { e-Belediye Bilgi Sistemi Projesi } \\
\text { (2017) }\end{array}$ & $\begin{array}{l}2014 \text { yılında İçişleri Bakanlığı tarafından Mülga Kalkınma } \\
\text { Bakanlığına sunulan proje, } 2017 \text { yılında onaylanmıştır. } \\
\text { Ülkemizde dijital dönüşümün yerel ayağı olarak adlandırlan } \\
\text { proje, belediyelerin elektronik ortamda, ortak altyapı } \\
\text { kullanarak ve tek veri tabanında işlem süreçlerini } \\
\text { yürütebilmelerini ve yerel hizmetlerin vatandaşa elektronik } \\
\text { ortamda sunulmasını içermektedir. }\end{array}$ \\
\hline
\end{tabular}

Görsel 1: Türkiye'de Yerel Yönetimlerde E-Yönetişim: Proje, Plan ve Uygulamalar

Görsel 1'de görüldügü üzere Türkiye'de yerel yönetimlerin bilgi ve iletişim teknolojilerinden faydalanarak bazı işlem ve hizmetlerinin sanal ortama taşınması öncelikle YerelNET ve YERELBILLGİ Projeleri yoluyla gerçekleşmiştir. Vatandaşın bu hizmetlerden sanal ortamda yararlanmasının önünü açan proje ise e-Belediye Bilgi Sistemidir. Türkiye'de belediyelerin e-Belediye Bilgi Sistemini kullanmaları, 2018 yılında kabul edilen 7099 sayılı "Yatırım Ortamının İyileştirilmesi Amacıyla Bazı Kanunlarda Değişiklik Yapılmasına Dair Kanun" ile zorunlu hale getirilmiştir. 7099 sayılı kanunun 16. Maddesi ile 5393 sayılı Belediye Kanunu'na eklenen ek maddeye göre;

\begin{abstract}
"Belediyeler, mevzuatla kendilerine verilen görev ve hizmetlerin yürütülmesi ve vatandaşlar tarafından yapılan başvuruların sonuçlandırılması amacıyla her türlü idari iş ve işlemin yürütüldüğü e-Belediye bilgi sistemini kullanır. e-Belediye bilgi sistemini kurmaya, işletmeye, veri saklama, veri iletimi ve veri paylaşımı ile ilgili politikaları tespit etmeye, çalışma usul ve esaslarını belirlemeye ve bu sistem ile ilgili merkezî bir hizmet standardizasyonu oluşturmaya İçişleri Bakanlığı yetkilidir."
\end{abstract}

Söz konusu kanun değişikliği ile belediyeler e-belediyecilik konusunda yasal dayanağa kavuşmuş oldular. Böylece yerel düzeyde belediyeler bilgi ve iletişim teknolojilerinin imkanlarından faydalanarak hizmetlerini elektronik ortamda sunabilecek ve bu ortam üzerinden vatandaşların talep ve beklentilerini karşılamaya yönelik işlemler gerçekleştirebileceklerdir.

\title{
Yerel Yönetimlerin E-Yönetişim Uygulamalarının Karşılaştırmalı Analizi: Ege Bölgesi Büyükşehir ve İl Belediyeleri Örneği
}

E-yönetişim, yönetişim yaklaşımının ana değerlerini sanal ortama taşıyarak kamuda katılımcı, demokratik ve şeffaf bir yapı oluşturmayı hedeflemektedir (Parlak ve Doğan, 2019). Çalışma kapsamında e-yönetişimin yerel yönetimlerdeki uygulaması olarak ele alınan "e-belediyecilik" ile sağlanması beklenen temel faydaların, yerelde demokrasiyi geliştirmek ve vatandaş katılımını arttırmak (Henden ve Henden, 2005) olduğu göz önünde bulundurulduğunda, belediyelerin internet 
sitelerini ve e-belediyecilik kapılarını bu unsurları destekleyecek şekilde düzenlemeleri beklenmektedir. Bunların yanı sıra e-belediyecilik uygulamalarının diğer bir amacı da belediyelerin sorumluluğunda olan birtakım hizmetlerin belediyelere ait internet sitelerinden zahmetsiz ve hızlı bir şekilde gerçekleştirilmesini sağlamaktır. TASAM (2006) bünyesinde Polat tarafından hazırlanan "E-Belediyecilik Kılavuzu Yerel Yönetimler Vatandaș Etkileşimi" başlıklı raporda, e-belediyenin parametreleri; "belediye hizmetlerinin sağlanması, demokratik yönetişim ve yönetsel etkinlik" olarak gruplandırılmıștır. Ayrıca e-yönetişim ile doğrudan ilgili olan ve demokratik yönetişimin alt boyutu olarak değerlendirilen (Uzun, 2019, 45) e-katılım ile ilgili bazı çalıșmaların, e-katılım parametreleri konusunda ortak noktaları "e-bilgilendirme ve e-danışma" (OECD, 2001-2003 raporları; Wimmer, 2007;Al-Dalou ve Abu-Shanab, 2013) unsurlarını içermeleridir. Özetle, e-yönetişim anlayışının yerel yönetimlerde yerleşmesi için uygun bir seçenek olan "e-belediyecilik" uygulamalarının; "vatandaşın bilgi edinmesini, yönetsel kararlara katılımını, hizmetlere kolay ulaşımını" sağlayabildiği ölçüde etkili olacağı söylenebilir.

Belediyelere ait internet sitelerinin belirtilen unsurlara yer vermesinin yanında vatandaşın ebelediyecilik uygulamalarını kullanabilirliği açısından bu sitelerin işlevselliği de önemlidir. İşlevsel bir internet sitesi için en temel şartlar "siteye ulaşım kolaylı̆̆ı; yapısal, içeriksel ve işlevsel özelliklerinin kullanıcılar tarafından algılanabilme kolaylığı; kullanıcıların aradıkları öğeyi bulma hızı, site haritasının varlığı" (Flavian, Guinalíu ve Gurrea, 2005) șeklinde sıralanmaktadır. Bunun yanı sıra internet üzerinden sağlanması ve çevrimiçi işlemlere dayanması dolayısıyla, vatandaşın işlemleri sırasında gizlilik/güvenlik hususlarından haberdar edilmesi ve kişisel bilgilerinin nerelerde kullanılacağı ya da işlemlerinden ne şekilde sorumlu tutulabileceği konusunda bilgilendirilmesi de önem arz etmektedir (Sayımer ve diğerleri, 2019).

\section{Çalışmanın Amacı, Kapsamı ve Yöntemi}

Çalışmada yerel yönetim politika ve uygulamalarının e-yönetişim parametreleri kapsamında incelenmesi amaçlanmaktadır. Çalışma konusu; "Belediyelerin internet siteleri; etkili e-yönetişimin sağlanması ve işlevsel bir uygulama olması konusunda gerekli görülen "kamu bilgilerine erişim, çevrimiçi katılım ve danışma, çevrimiçi belediye hizmetleri, kullanılabilirlik ve gizlilik/güvenlik özellikleri" konularında yeterli düzeyde midir? Sıralanan konulara ilişkin çevrimiçi uygulamaların yeterliliği açısından belediyeler birbirinden farklılaşmakta mıdır?" soruları bağlamında ele alınmış ve sinırlanmıştır.

Çalışmada, örneklem olarak Ege Bölgesi büyükşehir ve il belediyeleri (Aydın, Denizli, İzmir, Manisa, Muğla Büyükşehir Belediyeleri ile Afyonkarahisar, Kütahya ve Uşak Belediyeleri) seçilmiştir. Resmi internet siteleri incelenerek bu belediyelerin e-yönetişim politikaları karşılaştırmalı olarak analiz edilmiştir. Bu doğrultuda "etkili e-yönetişimin sağlanmasına yönelik e-belediyecilik uygulamaları" ve "e-belediyecilik uygulamalarının kullanılabilirlik ve gizlilik/güvenlik özellikleri" olmak üzere iki ana başlık belirlenmiştir. İlk ana başlığın alt başlıklarının (kamu bilgilerine erişim, çevrimiçi katılım ve danışma, çevrimiçi belediye hizmetleri) ve alt başlıklara yönelik değişkenlerin belirlenmesinde başta Polat (2006) tarafından hazırlanan "E-Belediyecilik Kılavuzu Yerel Yönetimler Vatandaş Etkileşimi" raporu olmak üzere, OECD (2001-2003) raporları, Wimmer (2007), Al-Dalou ve Abu-Shanab (2013)'ın çalışmalarından faydalanılmıştır. İkinci ana başlığın alt başlıkları (belediye internet sitelerinin kullanılabilirlik özellikleri, belediye internet sitelerinin gizlilik/güvenlik özellikleri) ve alt başlıklara yönelik değişkenleri ise Flavian ve diğerleri (2005), Polat (2006) ve Sayımer ve diğerleri (2019)'nin çalışmalarından faydalanılarak oluşturulmuştur.

Çalışmanın kapsamında örneklem olarak seçilen sekiz belediyeye ait resmi internet siteleri içerik analizine tabi tutulmuştur. Analiz değişkenleri "var, yeterli (+); var, yetersiz $( \pm)$; ve yok $(-)$ " şeklinde üç kategori olarak belirlenmiştir. Analiz sonuçları tablolar haline getirilerek değerlendirme konusu yapılmıştır. Ayrıca analiz kapsamında belediyelerin yüksek (8-7), orta (6-5-4), düşük düzeyde yer verdikleri (3-2-1) ve hiç yer vermedikleri (0) kategoriler incelenmiştir. Çalışma sekiz belediye ile gerçekleștirildiğinden, 8-7 belediyede bulunan özellikler yüksek, 6-5-4 belediyede bulunan özellikler orta, 3-2-1 belediyede bulunan özellikler düşük olarak değerlendirilmiștir.

Çalışmada kullanılan ölçek, OECD (2001-2003) raporları ve Wimmer (2007), Al-Dalou ve AbuShanab (2013), Flavain vd. (2005), Polat(2006), Sayımer vd. (2019) çalışmalarından yararlanılarak aşağıdaki şekilde oluşturulmuştur. 
Etkili E-Yönetişimin Sağlanmasına Yönelik E-Belediyecilik Uygulamaları

\begin{tabular}{|c|c|}
\hline Ana Başlık & Değişkenler \\
\hline Kamu Bilgilerine Erişim & $\begin{array}{ll}\text { - } & \text { Belediye Hakkında Genel Bilgi } \\
\text { - } & \text { Belediyenin Tarihçesi } \\
\text { - } & \text { Belediyenin Vizyon ve Misyonu } \\
\text { - } & \text { Belediyenin Değerleri } \\
\text { - } & \text { Belediyenin Stratejik Planı } \\
\text { - } & \text { Belediye Teşkilat Şeması } \\
\text { - } & \text { Belediye Meclis Toplantıları ve Kararları } \\
\text { - } & \text { Belediye Faaliyet Raporları } \\
\text { - } & \text { Belediye Etkinlik Takvimi } \\
\text { - } & \text { Belediye Basın Arşivi } \\
\text { - } & \text { Belediye'ye Ait Sosyal Medya Hesap Linkleri } \\
\text { - } & \text { İlillçe Tanıtım Bilgisi }\end{array}$ \\
\hline \multirow[t]{2}{*}{$\begin{array}{c}\text { Çevrimiçi Katılım ve } \\
\text { Danışma }\end{array}$} & 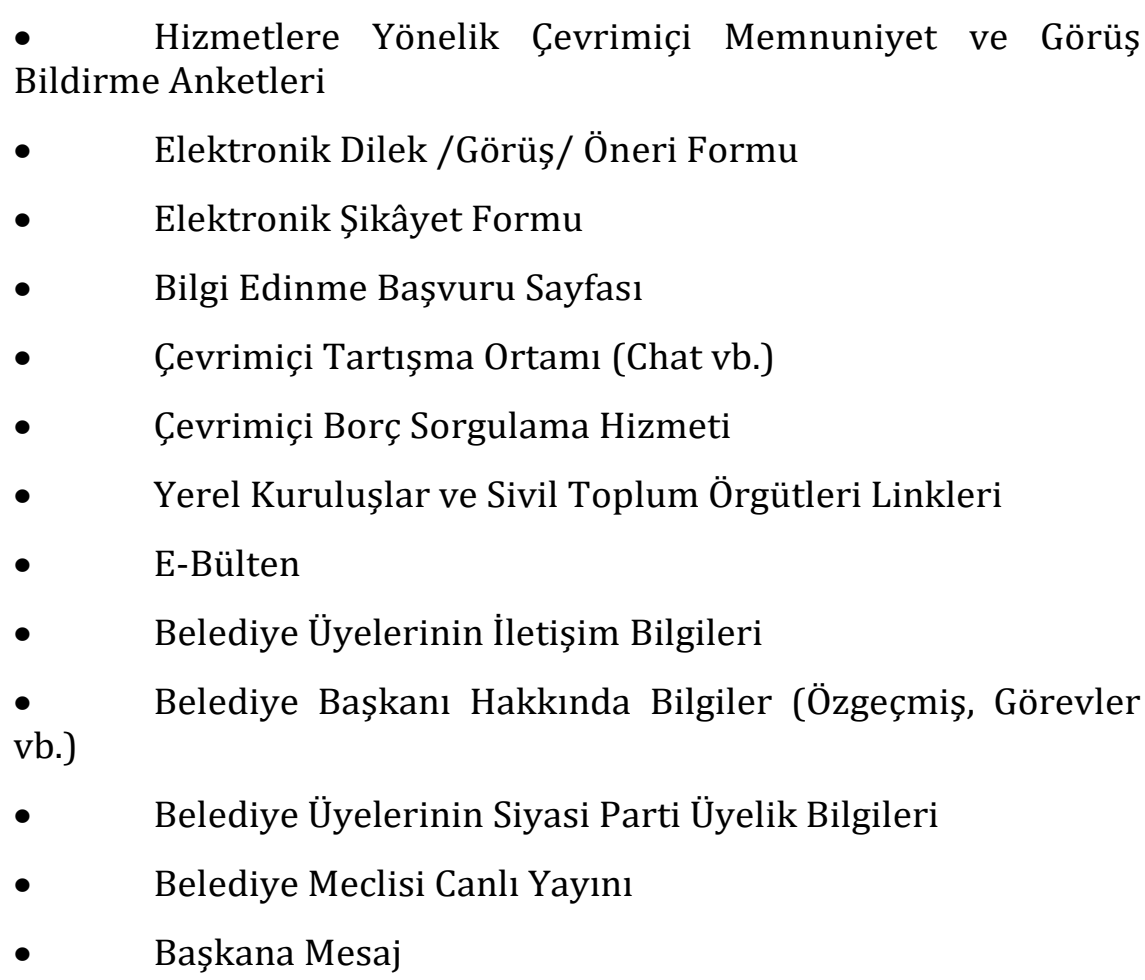 \\
\hline & 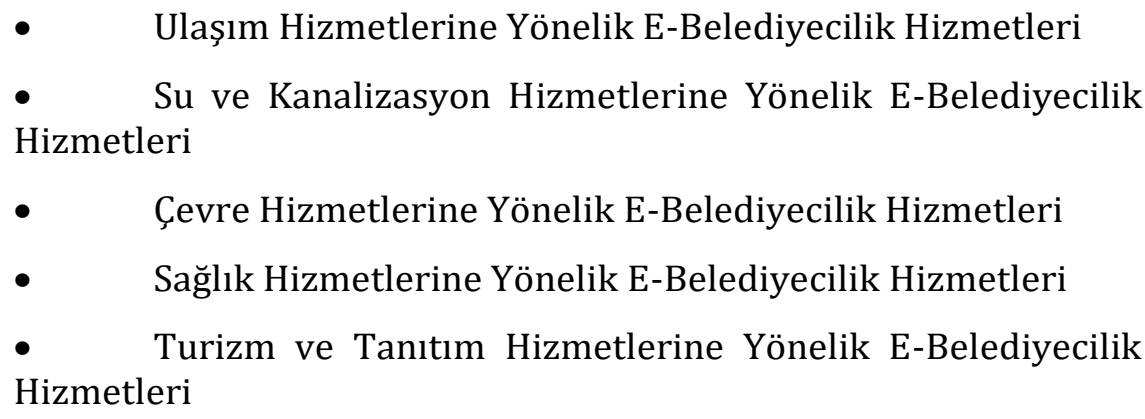 \\
\hline
\end{tabular}




\begin{tabular}{|c|c|}
\hline $\begin{array}{c}\text { Çevrimiçi Belediye } \\
\text { Hizmetleri }\end{array}$ & $\begin{array}{l}\text { - İmar ve Planlama Hizmetlerine Yönelik E-Belediyecilik } \\
\text { Hizmetleri } \\
\text { - Meslek ve Beceri Kazandırmaya Yönelik E-Belediyecilik } \\
\text { Hizmetleri } \\
\text { - Nikâh Hizmetlerine Yönelik E-Belediyecilik Hizmetleri } \\
\text { - Cenaze ve Defin İşlemlerine Yönelik E-Belediyecilik } \\
\text { Hizmetleri } \\
\text { - Kültür ve Spor Hizmetlerine Yönelik E-Belediyecilik } \\
\text { Hizmetleri }\end{array}$ \\
\hline
\end{tabular}

E-Belediyecilik İnternet Sayfalarının Kullanılabilirlik ve Gizlilik/Güvenlik Özellikleri

\begin{tabular}{|c|c|}
\hline Ana Başlık & Değişkenler \\
\hline $\begin{array}{l}\text { Belediye İnternet Sitelerinin } \\
\text { Kullanılabilirlik Özellikleri }\end{array}$ & 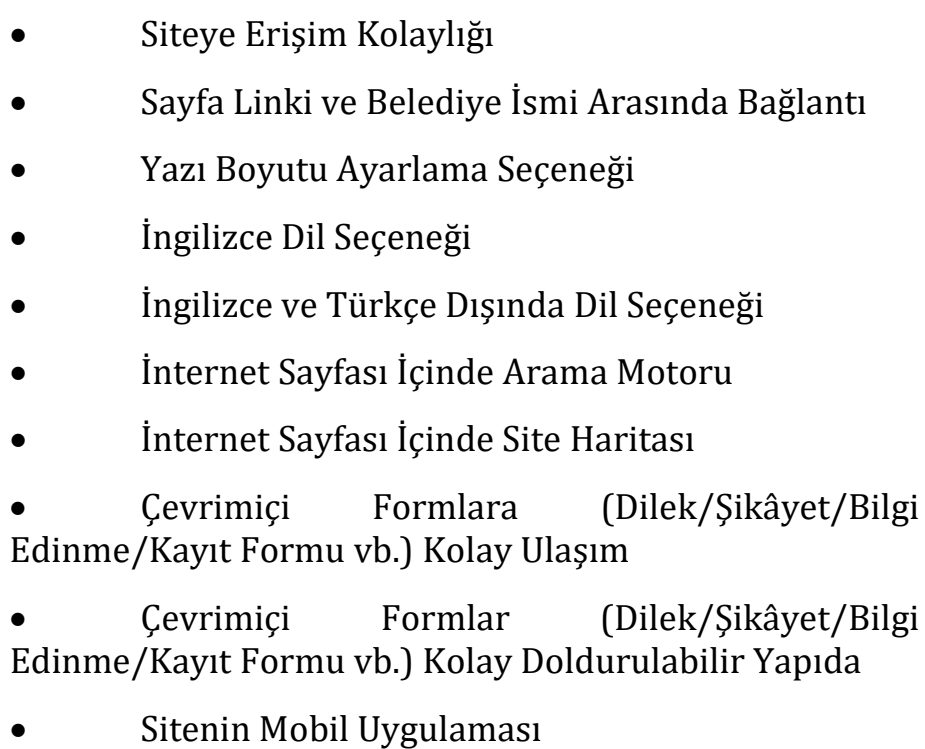 \\
\hline $\begin{array}{l}\text { Belediye İnternet Sitelerinin } \\
\text { Gizlilik/Güvenlik Özellikleri }\end{array}$ & $\begin{array}{ll}\text { - } & \text { Gizlilik/Güvenlik Politikası Hakkında Bilgi } \\
\text { - } & \text { Gizlilik/Güvenlik Politikasını Onaylama Butonu } \\
\text { - } & \text { Kişisel Verilerin Üçüncü Şahıslarla Paylaşılıp } \\
\text { Paylaşılmadığı Hakkında Bilgi } \\
\text { - } \quad \text { Isşlem Gerçekleştirmek İçin Kullanıcı Adı ve Şifre } \\
\text { Gerekliliği } \\
\text { İşlemi } & \text { Güvenlik Doğrulama Sistemi İle Hesap Kurtarma }\end{array}$ \\
\hline
\end{tabular}

Görsel 2: Çalışmada Kullanılan Değişkenlere İlişskin Ölçek

\section{Çalışmanın Bulguları}

Çalışmada örneklem olarak seçilen Ege Bölgesi büyükșehir ve il belediyelerinin resmi internet siteleri eyönetişim politikaları üzerinden karşılaştırmalı olarak aşağıdaki görselde (Görsel 3) sunulmuştur. 


\begin{tabular}{|c|c|c|c|c|c|c|c|c|c|c|}
\hline No. & Kategori & 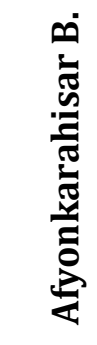 & 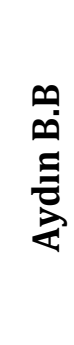 & 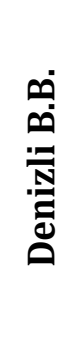 & $\stackrel{\infty}{\mathscr{\Xi}}$ & 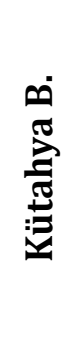 & 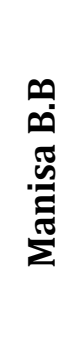 & 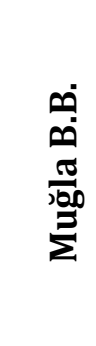 & 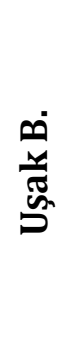 & $\sum_{\substack{a \\
0}}$ \\
\hline \multicolumn{11}{|c|}{ Kamu Bilgilerine Erişim } \\
\hline 1. & $\begin{array}{l}\text { Belediye Hakkında } \\
\text { Genel Bilgi }\end{array}$ & - & + & + & + & + & + & - & - & 5 \\
\hline 2. & Belediyenin Tarihçesi & - & + & + & + & + & + & - & - & 5 \\
\hline 3. & $\begin{array}{l}\text { Belediyenin Vizyon Ve } \\
\text { Misyonu }\end{array}$ & - & + & + & + & + & + & + & - & 6 \\
\hline 4. & Belediyenin Değerleri & - & - & + & - & - & + & + & - & 3 \\
\hline 5. & $\begin{array}{l}\text { Belediyenin Stratejik } \\
\text { Planı }\end{array}$ & + & + & - & + & - & - & + & + & 5 \\
\hline 6. & $\begin{array}{l}\text { Belediye Teşkilat } \\
\text { Şeması }\end{array}$ & + & + & + & - & + & + & + & + & 7 \\
\hline 7. & $\begin{array}{l}\text { Belediye Meclis } \\
\text { Toplantıları ve } \\
\text { Kararları }\end{array}$ & + & + & + & + & + & + & + & + & 8 \\
\hline 8. & $\begin{array}{l}\text { Belediye Faaliyet } \\
\text { Raporları }\end{array}$ & + & + & + & + & - & + & + & + & 7 \\
\hline 9. & $\begin{array}{l}\text { Belediye Etkinlik } \\
\text { Takvimi }\end{array}$ & \pm & + & - & + & - & + & + & + & 6 \\
\hline 10. & Belediye Basın Arşivi & + & + & + & + & + & + & + & + & 8 \\
\hline 11. & $\begin{array}{l}\text { Belediye'ye Ait Sosyal } \\
\text { Medya Hesap Linkleri }\end{array}$ & + & \pm & + & + & + & + & + & + & 7 \\
\hline 12. & İl/İlçe Tanıtım Bilgisi & + & + & + & + & + & \pm & + & \pm & 6 \\
\hline \multicolumn{2}{|c|}{ Toplam } & 6 & 10 & 10 & 10 & 8 & 10 & 10 & 7 & \\
\hline \multicolumn{11}{|c|}{ Çevrimiçi Katılım Ve Danışma } \\
\hline 1. & $\begin{array}{l}\text { Hizmetlere Yönelik } \\
\text { Çevrimiçi Memnuniyet } \\
\text { ve Görüş Bildirme } \\
\text { Anketleri }\end{array}$ & + & + & + & + & + & + & - & + & 7 \\
\hline
\end{tabular}




\begin{tabular}{|c|c|c|c|c|c|c|c|c|c|c|}
\hline 2. & $\begin{array}{l}\text { Elektronik Dilek } \\
\text { /Görüş/ Öneri Formu }\end{array}$ & + & + & + & + & - & \pm & + & - & $\mathbf{5}$ \\
\hline 3. & $\begin{array}{l}\text { Elektronik Şikâyet } \\
\text { Formu }\end{array}$ & + & + & + & + & - & \pm & + & + & 6 \\
\hline 4. & $\begin{array}{l}\text { Bilgi Edinme Başvuru } \\
\text { Sayfası }\end{array}$ & + & + & + & + & + & + & + & + & 8 \\
\hline 5. & $\begin{array}{l}\text { Çevrimiçi Tartışma } \\
\text { Ortamı (Chat vb.) }\end{array}$ & - & - & - & - & - & - & - & - & $\mathbf{0}$ \\
\hline 6. & $\begin{array}{l}\text { Çevrimiçi Borç } \\
\text { Sorgulama Hizmeti }\end{array}$ & + & + & + & + & + & - & + & + & 7 \\
\hline 7. & $\begin{array}{l}\text { Yerel Kuruluşlar ve } \\
\text { Sivil Toplum Örgütleri } \\
\text { Linkleri }\end{array}$ & - & \pm & \pm & + & \pm & + & - & + & 3 \\
\hline 8. & E-Bülten & + & + & - & + & + & - & + & - & $\mathbf{5}$ \\
\hline 9. & $\begin{array}{l}\text { Belediye Üyelerinin } \\
\text { İletişim Bilgileri }\end{array}$ & \pm & - & \pm & - & \pm & - & - & \pm & $\mathbf{0}$ \\
\hline 10. & $\begin{array}{l}\text { Belediye Başkanı } \\
\text { Hakkında Bilgiler } \\
\text { (Özgeçmiş, Görevler } \\
\text { vb.) }\end{array}$ & + & + & + & + & + & + & + & + & 8 \\
\hline 11. & $\begin{array}{l}\text { Belediye Üyelerinin } \\
\text { Siyasi Parti Üyelik } \\
\text { Bilgileri }\end{array}$ & + & + & + & + & - & - & + & + & 6 \\
\hline 12 . & $\begin{array}{l}\text { Belediye Meclisi Canlı } \\
\text { Yayını }\end{array}$ & - & - & - & + & + & - & + & + & 4 \\
\hline 13. & Başkana Mesaj & + & + & - & - & + & + & - & + & 5 \\
\hline & Toplam & 9 & 9 & 7 & 10 & 7 & 5 & 8 & 9 & \\
\hline \multicolumn{11}{|c|}{ Çevrimiçi Belediye Hizmetleri } \\
\hline 1. & $\begin{array}{l}\text { Ulaşım Hizmetlerine } \\
\text { Yönelik E-Belediyecilik } \\
\text { Hizmetleri }\end{array}$ & + & + & + & + & + & + & + & + & 8 \\
\hline 2. & $\begin{array}{l}\text { Su ve Kanalizasyon } \\
\text { Hizmetlerine Yönelik } \\
\text { E-Belediyecilik } \\
\text { Hizmetleri }\end{array}$ & \pm & + & + & + & - & + & - & - & 4 \\
\hline 3. & $\begin{array}{l}\text { Çevre Hizmetlerine } \\
\text { Yönelik E-Belediyecilik } \\
\text { Hizmetleri }\end{array}$ & - & - & + & + & + & + & - & - & 4 \\
\hline 4. & $\begin{array}{l}\text { Sağlık Hizmetlerine } \\
\text { Yönelik E-Belediyecilik } \\
\text { Hizmetleri }\end{array}$ & + & + & \pm & + & \pm & + & - & \pm & 4 \\
\hline
\end{tabular}




\begin{tabular}{|c|l|c|c|c|c|c|c|c|c|c|}
\hline 5. & $\begin{array}{l}\text { Turizm ve Tanitım } \\
\text { Hizmetlerine Yönelik } \\
\text { E-Belediyecilik } \\
\text { Hizmetleri }\end{array}$ & \pm & + & + & + & + & \pm & + & + & $\mathbf{6}$ \\
\hline 6. & $\begin{array}{l}\text { İmar ve Planlama } \\
\text { Hizmetlerine Yönelik } \\
\begin{array}{l}\text { E-Belediyecilik } \\
\text { Hizmetleri }\end{array}\end{array}$ & + & \pm & + & + & + & + & + & + & $\mathbf{7}$ \\
\hline 7. & $\begin{array}{l}\text { Meslek ve Beceri } \\
\text { Kazandırmaya Yönelik } \\
\text { E-Belediyecilik } \\
\text { Hizmetleri }\end{array}$ & \pm & - & - & + & - & - & - & - & $\mathbf{1}$ \\
\hline 8. & $\begin{array}{l}\text { Nikâh Hizmetlerine } \\
\text { Yönelik E-Belediyecilik } \\
\text { Hizmetleri }\end{array}$ & + & - & + & - & - & - & - & + & $\mathbf{3}$ \\
\hline 9. & $\begin{array}{l}\text { Cenaze ve Defin } \\
\text { Islemlerine Yönelik E- } \\
\text { Belediyecilik } \\
\text { Hizmetleri }\end{array}$ & + & - & + & + & + & + & + & + & $\mathbf{7}$ \\
\hline 10. & $\begin{array}{l}\text { Kültür ve Spor } \\
\text { Hizmetlerine Yönelik } \\
\text { E-Belediyecilik } \\
\text { Hizmetleri }\end{array}$ & \pm & + & + & + & - & + & + & + & $\mathbf{6}$ \\
\hline
\end{tabular}

Görsel 3: Ege Bölgesi Büyükșehir ve İl Belediyelerinin Resmi İnternet Sitelerinin E-Yönetişim Politikaları Yönünden Karşılaştırmalı Analizi

Belediyelerin kurumsal internet siteleri, etkili e-yönetişimin sağlanması kapsamında, "kamu bilgilerine erişim, çevrimiçi katılım ve danışma, çevrimiçi belediye hizmetleri” başlıkları altında analiz edilmiştir. Her başlık altında yer alan analiz değişkenleri doğrultusunda incelenen sitelerin genel görünümü ana başlık sırasına göre şu şekilde değerlendirilmiştir:

\section{Kamu Bilgilerine Erişim}

"Kamu bilgilerine erişim" ana başlığı; belediye hakkında genel bilgiler, belediyenin tarihçesi, belediyenin değerleri, meclis kararları, faaliyet raporları dâhil olmak üzere toplamda 12 değişken ile değerlendirilmiștir. Görsel 3'e göre Aydın, Denizli, İzmir, Manisa ve Muğla Büyükșehir Belediyeleri toplamda 10 değişkeni karşılarken, Kütahya Belediyesi 8, Uşak Belediyesi 7 ve Afyonkarahisar Belediyesi 6 değişkeni karşılamaktadır.

Örnekleme dâhil belediye internet sayfalarında yer alan kamu bilgilerine erişim hizmetleri; "yüksek (8-7), orta(6-5-4) ve düşük(3-2-1) düzeyde" olmak üzere üç düzey esas alınarak incelenmiştir. Buna göre belediye internet sayfalarında yüksek düzeyde yer verilen hizmetler "meclis toplantı ve kararlarına erişim/belediye basın arşivi/teşkilat șeması/faaliyet raporları/sosyal medya hesap linkleri" dir. Orta düzeyde yer verilen hizmetler "vizyon-misyon/etkinlik takvimi/il ilçe tanıtımı/belediye hakkında genel bilgi/tarihçe/stratejik plan" olarak belirlenmiştir. Düşük düzeyde yer verilen hizmet ise yalnızca üç belediye (Denizli, Manisa ve Muğla Büyükşehir Belediyeleri) tarafından vatandaşa sunulan "belediyenin değerleri" hususudur. 


\begin{abstract}
"Kamu bilgilerine erişim" kapsamında örnekleme dâhil belediyelerin bilgi ve belge sunma yönüyle birbirinden kısmen farklılaştıkları görülmektedir. Bu bağlamda ilgili belediyelerin kurumsal bilgilerden vatandaşı yeterli düzeyde haberdar ettiği anlaşılmaktadır. Ancak sekiz belediyeden yalnızca üçünün belediye değerlerine yer vermesi bu hususun belediyelerce gözden geçirilmesini gerekli kılmaktadır. Yerel topluluğun belediyenin hangi yönetsel değerleri benimsediğini bilmesi hem aidiyet duygusu hem de şeffaf ve katılımcı yönetim için önemli bir unsurdur. Belediye internet sayfalarının çoğunda canlı destek uygulamasına yer verilmesi ve kimi belediyelerin (Afyonkarahisar, Kütahya ve Uşak Belediyeleri) whatsapp danışma hattı üzerinden vatandaşlara destek sağlaması, yerel yönetimin yönetilenlere yaklaşmasını sağlayacak uygulamalardır. Yönetsel diyaloğun güçlenmesiyle yerel topluluğun yerel hizmet sunumuna daha aktif şekilde katılımı mümkün olacaktır.
\end{abstract}

\title{
Çevrimiçi Katılım ve Danışma
}

"Çevrimiçi katılım ve danışma" ana başlı̆̆ı; vatandaş anketleri, çevrimiçi formlar (talep-şikâyet-bilgi edinme formları), e-bülten uygulaması dâhil olmak üzere toplamda 13 değişken ile değerlendirilmiştir. Görsel 3'e göre incelenen belediyeler arasından toplamda 10 değişkene yer vererek en fazla unsuru karşılayan belediye, İzmir Büyükșehir Belediyesi'dir. Aydın ve Muğla Büyükşehir Belediyeleri ile Afyonkarahisar Belediyesi 9, Manisa Büyükşehir Belediyesi 8, Muğla Büyükşehir Belediyesi ve Kütahya Belediyesi 7 değişkeni karşılamaktadır.

Çalışma kapsamında belediye internet sayfalarında yer alan çevrimiçi katılım ve danışma hizmetleri; "yüksek (8-7), orta (6-5-4) ve düşük (3-2-1) düzeyde" olmak üzere ele alınmıștır. Yapılan incelemede, belediye internet sayfalarında yüksek düzeyde yer verilen hizmetler; "bilgi edinme başvuru sayfası/çevrimiçi vatandaş anketleri/borç sorgulama hizmeti/belediye başkanı hakkında bilgiler" olarak tespit edilmiştir. Orta düzeyde yer verilen hizmetler; "elektronik şikâyet formu/vatandaș katılımına yönelik çevrimiçi anketler/e-bülten/belediye üyelerinin siyasi parti üyelik bilgileri/başkana mesaj/belediye meclisi canlı yayını"dır. Düşük düzeyde yer verilen hizmetler ise yalnızca üç belediye (İzmir ve Manisa Büyükşehir Belediyeleri ile Uşak Belediyesi) tarafından karşılanan yerel kuruluşlar ve sivil toplum örgütlerine ait linklerin belediye sayfasında yer almasıdır. Belediye meclis üyelerinin iletişim bilgilerinin yeterli düzeyde ve eksiksiz şekilde sağlanamadığı görülmektedir. Ayrıca çevrimiçi tartışma ortamına yönelik hizmet (chat, sanal toplantı odaları vb.) hiçbir belediye tarafından karşılanamamıştır.

"Çevrimiçi katılım ve danışma" kapsamında yapılan analizde, belediyelerin karşıladıkları değişken sayısı göz önünde bulundurulduğunda, örneklemdeki belediyelerin birbirinden kısmen farklılaştığı görülmektedir. Kütahya Belediyesi, çevrimiçi talep/şikâyet formları yerine çözüm masası telefon ve e-posta hizmeti kullanmaktadır. Bu nedenle çalışma kapsamında "çevrimiçi form" varlığında değerlendirilen dilek ve şikâyet iletme araçları Kütahya Belediyesi'nde yok (-) şeklinde değerlendirilmiştir. Öte yandan hiçbir belediyenin çevrimiçi tartışma ortamına yönelik araçlar geliştirmemiş olması, çalışmada e-yönetişim kapsamında değerlendirilen, demokratik ve katılımcı yönetimin önemli unsurlarından olan "müzakere etme, ortak karar verme, ortak hareket etme" konularında belediye-vatandaş etkileşiminde eksikliğe işaret etmektedir. Dolayısıyla belediye internet sayfalarında, yönetime katılımın arttırılmasına yönelik sohbet ve sanal toplantı odaları oluşturulması e-yönetişimi güçlendirecektir. Vatandaş anketlerinin birçok belediyenin internet sitesinde aktif olarak kullanılması vatandaşların, yerel kamu politikalarının oluşum ve değerlendirmesi aşamasına katılımlarını mümkün kılmaktadır. Aydın ve Denizli Büyükșehir Belediyeleri, 2020-2024 dönemi için stratejik planlamalarını bu anketleri kullanarak vatandaş ile işbirliği içinde gerçekleştireceklerini resmi sitelerinde duyurmuşlardır.

\section{Çevrimiçi Belediye Hizmetleri}

"Çevrimiçi belediye hizmetleri" ana başlığı; ulaşım hizmetleri, su ve kanalizasyon hizmetleri, kültür ve spor hizmetleri dâhil olmak üzere toplamda 10 değişken ile değerlendirilmiştir. Görsel 3'e göre incelenen belediyeler arasında toplamda 9 değişkene yer vererek en fazla unsuru karşıllayan belediye, İzmir Büyükşehir Belediyesi'dir. Bu belediyeyi 8 değișken ile Denizli Büyükșehir Belediyesi izlemektedir. Manisa Büyükşsehir Belediyesi 7, Uşak Belediyesi 6, Aydın ve Muğla Büyükşsehir Belediyeleri ile Afyonkarahisar ve Kütahya Belediyeleri ise 5 değişkeni karşılamaktadır. 
Çalışma kapsamında belediye internet sayfalarında yer alan çevrimiçi belediye hizmetleri; "yüksek (8-7), orta (6-5-4) ve düşük (3-2-1) düzeyde" olmak üzere üçlü tasnife tabi tutulmuştur. Bu tasnife göre belediye internet sayfalarında yüksek düzeyde yer verilen hizmetler; "ulaşım/cenaze ve defin/imar ve planlama" hizmetleridir. Orta düzeyde ise; "turizm ve tanıtım/kültür ve spor/su ve kanalizasyon/çevre/sağlık" hizmetleri bulunmaktadır. Düşük düzeyde sağlanan çevrimiçi belediye hizmetleri üç belediye (Denizli Büyükșehir Belediyesi ile Afyonkarahisar ve Ușak Belediyeleri) tarafından yer verilen nikâh hizmetleri ve yalnızca bir belediye (İzmir Büyükșehir Belediyesi) tarafından yer verilen meslek ve beceri edindirme hizmetleridir.

"Çevrimiçi belediye hizmetleri" kapsamında yapılan analizde, belediyelerin karşıladıkları değişken sayıları göz önünde tutulduğunda, örneklemdeki belediyelerin birbirinden anlamlı bir şekilde farklılaştığı görülmektedir. Çevrimiçi belediye hizmetleri hususunda yeterlilik ölçüsü de belediyeden belediyeye farklılaşmaktadır. Ancak ilgili belediyelerin konuya ilişkin değişkenlerden en az yarısını karşılaması çevrimiçi belediye hizmetlerinin yerel halka orta yeterlilikte sunulduğunu göstermektedir. Bununla birlikte e-yönetişimin daha işlevsel olabilmesi için belediyelerin konuya ilişkin yeterliliklerini arttırmaları gerekmektedir. Amaçlarından birisi halkın talep ve ihtiyaçlarına daha hızlı cevap vermek olan e-yönetişim yaklaşımı kapsamında, istihdamı geliştirmeye ve destekleyemeye yönelik uygulamalardan olan meslek ve beceri edindirmeye yönelik hizmetlere daha fazla önem verme ihtiyacı belediyelerde kendini göstermektedir. İzmir Büyükşehir Belediyesi'ne ait uygulamalardan olan "Meslek Fabrikası" uygulaması, çevrimiçi kurs kayıt sistemine sahip olması, hizmet hakkında detaylı bilgi içermesi (vizyon-misyon, organizasyon şeması gibi) ve mesleklere ve kurslara iliş̧in bilgileri vatandaşla paylaşması yönüyle dikkat çeken bir uygulamadır.

Çalışmada örneklem olarak seçilen Ege Bölgesi büyükșehir ve il belediyelerinin resmi internet siteleri kullanılabilirlik ve gizlilik/güvenlik özellikleri kapsamında karşılaştırmalı olarak aşağıdaki görselde (Görsel 4) sunulmuştur.

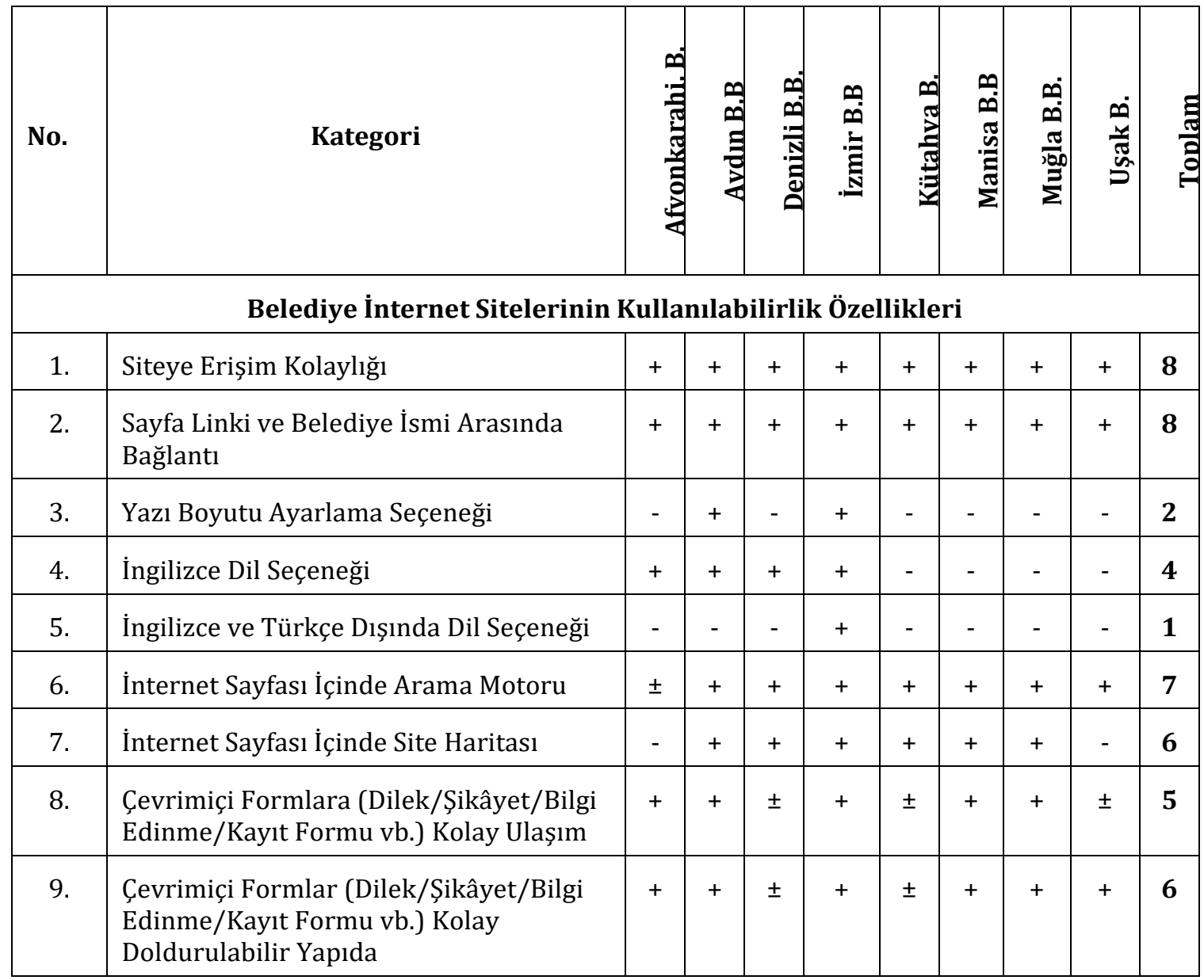




\begin{tabular}{|c|c|c|c|c|c|c|c|c|c|c|}
\hline 10. & Sitenin Mobil Uygulaması & \pm & - & + & + & \pm & - & + & - & 3 \\
\hline & Toplam & 5 & 8 & 6 & 10 & 5 & 6 & 7 & 4 & \\
\hline \multicolumn{11}{|c|}{ Belediye İnternet Sitelerinin Gizlilik/Güvenlik Özellikleri } \\
\hline 1. & $\begin{array}{l}\text { Gizlilik/Güvenlik Politikası Hakkında } \\
\text { Bilgi }\end{array}$ & + & - & + & + & - & + & + & + & 6 \\
\hline 2. & $\begin{array}{l}\text { Gizlilik/Güvenlik Politikasını Onaylama } \\
\text { Butonu }\end{array}$ & - & - & - & - & - & - & - & - & 0 \\
\hline 3. & $\begin{array}{l}\text { Kişisel Verilerin Üçüncü Şahıslarla } \\
\text { Paylaşılıp Paylaşılmadığı Hakkında Bilgi }\end{array}$ & - & - & - & + & - & - & + & + & 3 \\
\hline 4 & $\begin{array}{l}\text { İşlem Gerçekleştirmek İçin Kullanıcı Adı } \\
\text { ve Şifre Gerekliliği }\end{array}$ & + & + & + & + & + & + & + & + & 8 \\
\hline 5. & $\begin{array}{l}\text { Güvenlik Doğrulama Sistemi İle Hesap } \\
\text { Kurtarma İșlemi }\end{array}$ & + & + & + & + & + & + & + & + & 8 \\
\hline & Toplam & 2 & 2 & 3 & 4 & 2 & 3 & 4 & 4 & \\
\hline
\end{tabular}

Görsel 4: Ege Bölgesi Büyükșehir ve İl Belediyelerinin Resmi İnternet Sitelerinin Kullanılabilirlik ve Gizlilik/Güvenlik Kapsamında Karşılaştırmalı Analizi

Belediyelerin kurumsal internet siteleri, kullanılabilirlik ve gizlilik/güvenlik kapsamında, "belediye internet sitelerinin kullanılabilirlik özellikleri ve belediye internet sitelerinin gizlilik/güvenlik özellikleri" başlıkları altında analiz edilmiştir. Her başlık altında yer alan analiz değişkenleri doğrultusunda incelenen sitelerin genel görünümü ana başlık sırasına göre şu şekilde değerlendirilmiştir:

\section{Belediye İnternet Sitelerinin Kullanılabilirlik Özellikleri}

"Belediye internet sitelerinin kullanılabilirlik özellikleri" ana başlığı; siteye erişim kolaylığı, yazı boyutu ve yazı dili seçeneği dâhil olmak üzere toplamda 10 değişken ile değerlendirilmiștir. Görsel 4'e göre, örneklemdeki belediyeler arasından tüm değişkenlere yer vererek en fazla unsuru karşılayan belediye, 10 değişkenle İzmir Büyükşehir Belediyesi'dir. Aydın Büyükşehir Belediyesi 8, Muğla Büyükşehir Belediyesi 7, Denizli ve Manisa Büyükşehir Belediyeleri 6, Afyonkarahisar ve Kütahya Belediyeleri 5 değişkeni karş̧larken Uşak Belediyesi ise yalnızca 4 değişkeni karşılamaktadır.

Analiz kapsamında belediye internet sayfalarının kullanılabilirlik özelliklerinde yer verilen unsurlar; "yüksek (8-7), orta (6-5-4) ve düşük (3-2-1) düzeyde" olmak üzere üçlü tasnife tabi tutulmuştur. Buna göre belediye internet sayfalarında yüksek düzeyde yer verilen unsurlar; "siteye erişim kolaylığı/belediye adı ve link arasında ilişki/sayfada arama motorunun bulunması" olarak tespit edilmiştir. Orta düzeyde yer verilen unsurlar; "site haritası/çevrimiçi formlara kolay ulaşım/çevrimiçi formların kolay doldurulması/İngilizce dil seçeneği" iken düşük düzeyde yer verilen unsurlar; "sitenin mobil uygulaması/ yazı boyutu ayarlama/ İngilizce ve Türkçe dışında dil seçeneği"dir.

Örneklemdeki belediyeler arasında internet sitelerinin kullanılabilirlik özellikleri bakımından İzmir Büyükşehir Belediyesi'nin tüm unsurları karşıladığı ve hizmet kullanıcılarına çeşitli alternatifler sunduğu görülmüştür. Örneğin İzmir Büyükşehir Belediyesi'nin internet sitesinde, İngilizce ve Türkçe dışında beş dil seçeneğine daha yer verilmesi dikkat çekmektedir. Belediyelerin internet sayfalarının kullanılabilirlik açısından ve değişkenlerin kullanım oranları bakımından birbirlerinden farklılaştığını belirtmek gerekir. İncelenen belediyelerin internet sitelerinin kullanılabilirlik özellikleri bakımından orta yeterlilikte olduğunu söylemek mümkündür. Aydın Büyükşehir Belediyesi internet sitesinde verilen bilgilere göre sitenin mobil uygulamasının yakın zamanda 
hizmete sunulacağı belirtilmektedir. Belediyelerin internet sitelerinin yazı boyutunun ayarlanabilir olması sadece iki belediye (Aydın ve İzmir Büyükșehir Belediyeleri) tarafından uygulanmaktadır. Diğer belediyelerin de kullanıcılara bu şekilde farklı seçenekler sunması kullanım kolaylı̆̆ını arttıracak bir faktördür.

\section{Belediye İnternet Sitelerinin Gizlilik/Güvenlik Özellikleri}

"Belediye internet sitelerinin gizlilik/güvenlik özellikleri" ana başlığı; gizlilik/güvenlik politikalarına yer verilmesi, işlem gerçekleştirmek için kullanıcı adı ve şifre gerekliliği dâhil olmak üzere toplamda 5 değişken ile değerlendirilmiştir. Görsel 4'e göre, örneklemdeki belediyeler arasında toplamda 4 değişkene yer vererek bu unsuru en fazla karşllayan belediyeler, İzmir ve Muğla Büyükşehir Belediyeleri ile Uşak Belediyesi'dir. Denizli ve Manisa Büyükșehir Belediyeleri 3, Aydın Büyükşehir Belediyesi ile Afyonkarahisar ve Kütahya Belediyeleri 2 değişkeni karşılamaktadır.

Analiz kapsamında belediye internet sayfalarının gizlilik/güvenlik özelliklerinde yer verilen unsurlar; "yüksek (8-7), orta (6-5-4) ve düşük(3-2-1) düzeyde" olmak üzere üçlü tasnife tabi tutulmuştur. Buna göre belediye internet sayfalarında yüksek düzeyde yer verilen gizlilik/güvenlik unsurları; "işlem gerçekleştirmek için kullanıcı adı ve şifre gerekliliği ile güvenlik doğrulama sistemi ile hesap kurtarma işlemi yapılabilmesi" olarak tespit edilmiștir. Ayrıca orta düzeyde yer verilen unsur; "gizlilik/güvenlik politikası hakkında bilgi" iken belediye internet sayfalarında bu bilgiye ilişkin bir onay butonu bulunmadığı da görülmektedir. Düşük düzeyde yer verilen unsur ise "kişisel verilerin üçüncü şahıslarla paylaşılıp paylaşılmadığı hakkında bilgi” olarak tespit edilmiştir.

Örneklem kapsamındaki belediyelerin gizlilik/güvenlik politikaları arasında büyük farklar olmadığını söylemek mümkündür. Belediyelerin, gizlilik politika şartlarını onaylama ve kişisel verilerin paylaşılması hakkında yeterli bilgilendirme yapmadıkları görülmektedir. Bu durum kişisel verilerin korunmasına ilişkin bir sorun alanı olarak kendini göstermektedir.

\section{Sonuç ve Değerlendirme}

Yönetişim yaklaşımının değerlerini, bilgi ve iletişim teknolojileriyle bütünleştirerek yönetişimi dijital alana taşıyan e-yönetişim, yerel düzlemde ele alındığında, yerelde demokratik ve katılımcı yönetimi güçlendiren bir uygulamadır. E-yönetişimin temel parametreleri doğrultusunda e-belediyecilik uygulamalarından beklenen ise kamu bilgilerine açıkça yer vermesi ve bilgilere kolay ulaşımı sağlaması, çevrimiçi katılımı mümkün kılması, belediye tarafından gerçekleştirilen hizmetlere çevrimiçi ortamda da erişimi sağlaması olarak ifade edilebilir. Aynı zamanda belediyelerin elektronik uygulamalarının kullanılabilirliği ve kullanıcılara güvenli sanal ortam oluşturmaları da uygulamaların işlevselliğini belirleyen unsurlar arasındadır.

Çalışmada, e-yönetişim parametrelerini oluşturan bu unsurların, e-belediyecilik uygulamalarında nasıl karş̧lık bulduğu, Ege Bölgesi büyükşehir ve il belediyeleri kapsamında analiz edilmiş ve çeşitli bulgulara ulaşılmıştır. Örnekleme dâhil belediyelerin e-yönetişim politikalarına olumlu yaklaștıkları ve bu yönde uygulamalar geliştirdikleri görülmekle birlikte yeterliliklerini arttırmak ve eyönetişimin öngördüğü yönetim yapısına ulaşmak adına daha etkili politikalar geliştirilmesi gereği kendini göstermektedir.

Çalışmada incelenen belediyeler kamu bilgilerine erişim, çevrimiçi katılım ve danışma, gizlilik/güvenlik politikaları hususlarında kısmen farklılaşırken çevrimiçi belediye hizmetleri ve kullanılabilirlik özellikleri açısından birbirinden anlamlı şekilde farklılaşmaktadır. Örnekleme dâhil belediyeler, e-yönetişimin öngördüğü şeffaf yönetim anlayışı kapsamında önem kazanan, vatandaşların kamu bilgilerine erişimi konusunda yeterli düzeyde içeriğe yer vermektedir. Bununla birlikte belediyeler tarafindan en az paylaşllan bilginin belediyenin değerlerine ilişkin bilgiler olduğu tespit edilmiştir. Ortak yönetim anlayışını hâkim kılan e-yönetişimin daha etkin hâle getirilmesi için belediyelerin değerlerini vatandaşla daha fazla paylaşması gerekmektedir. Yine e-yönetişim parametrelerinden olan demokratik ve katılımcı yönetim çerçevesinde önem kazanan çevrimiçi katılım ve danışma konusunda belediyelerin orta düzeyde yeterliliğe sahip olduğu tespit edilmiştir. Belediyelerin çevrimiçi katılım ve danışma konusunda mevcut içeriklerini geliştirmesi ve daha fazla katılım aracı oluşturması bu alandaki politika önceliklerine dâhil edilmelidir.

Çalışmada ele alınan bir diğer unsur çevrimiçi belediye hizmetlerine dijital ortamda ne kadar yer verildiğidir. Örnekleme dâhil belediyelerin sunmakla yükümlü olduğu hizmetleri çevrimiçi ortamda 
orta yeterlilikte gerçekleştirdikleri görülmektedir. Bununla birlikte e-yönetişim unsurlarından biri olan vatandaş merkezli yönetim anlayışı kapsamında belediyelerin vatandaşların beklentilerine (örneğin meslek ve beceri kazandırmaya yönelik hizmetler gibi) daha fazla cevap vermesi olumlu bir yaklaşım olacaktır. Belediye sitelerinin işlevselliği konusunda gerçekleştirilen değerlendirmede ise belediyelerin kullanılabilirlik özellikleri açısından orta yeterlilikte olduğu, gizlilik/güvenlik politikalarının ise vatandaşla yeterli düzeyde paylaşılmadığı ortaya çıkmaktadır. Vatandaşların kişisel bilginlerinin korunması ve siteye ilişkin gizlilik/güvenlik politikalarından haberdar edilmesi konusunda daha duyarlı yaklaşımlara işlevsellik kazandırma ihtiyacı ön plana çıkmaktadır.

\section{Yazar Katkıları}

Çalışmaya 1. Yazar: \%50, 2. Yazar: \%50, oranında katkı sağlamıştır.

\section{Kaynakça}

Al-Dalou, R. ve Emad A. (2013). E-Participation Levels and Technologies. The 6th International Conference on Information Technology (ICIT 2013).

Alodal, M. , Tuncer, A. , Usta, S. , Halis, M. . (2012). Yerel Yönetimlerde E-Belediyecilik Uygulamaları: Akdeniz Bölgesi Örneği. MANAS Sosyal Araștırmalar Dergisi, 1(1), 83-95 . Erişim adresi: https://dergipark.org.tr/en/pub/mjss/issue/40475/484883

Aygün, D. ve Satı Z.E. (2020). Doğu Asya'da Ortaya Çıkan Dijital Dönüşüm Kavramları Üzerine Bir Analiz. Strategic Public Management Journal, 6(12): 149-159. DOI: 10.25069/spmj.701366

Bannister, F. ve Connolly, R. (2012). Defining e-governance. e-Service Journal 8(2), 3-25. Erişim adresi: https://www.jstor.org/stable/10.2979/eservicej.8.2.3

Belli, A. ve Aydın, A. (2019). Yerel e-yönetişim: Türkiye'de e-yönetişimin yerele yansıması. Parlak B. ve Doğan K.C. (Ed.), E-yönetişim: kavramsal/kuramsal çerçeve, ülke incelemeleri ve Türkiye'ye yansımaları içinde (s. 489-508). İstanbul: BETA Yayıncılık.

Çark, Ö. (2020). İșletmelerin Dijital Dönüşüm Sürecinde “Nesnelerin İnterneti” Teknolojisinin Etkisi. Turkish Studies Economy, 15(3), 1247-1266. Erişim adresi: https://dx.doi.org/10.47644/TurkishStudies.41888

Dawes, S.S. (2008). The Evolution and Continuing Challenges of e-Governance. Public Administration Review, (Special Issue), s. 86-102. DOI: 10.1111/j.1540-6210.2008.00981.x.

Demirel, D. (2010). Yönetişimde Yeni Bir Boyut: E-Yönetişim. Türk Iddare Dergisi, (466), 65-94. Erişim adresi: http://www.tid.gov.tr/

Doğan, K.C. ve Ustakara F. (2013). "Kamuda Bir Yapılanma Dönüşümü Olarak E-Devlet ve EYönetişim İlişkisi Üzerine." Küresel İktisat ve İşletme Çalış̧maları Dergisi, 2(3), 1-11. Erişim adresi: http://www.gjebs.com - ISSN: 2147-415X

Ekşi, A. (2019). E-yönetişim ve katılım: e-demokrasinin faktörleri ve belirleyicileri. Parlak B. ve Doğan K.C. (Ed.), E-yönetişim: kavramsal/kuramsal çerçeve, ülke incelemeleri ve Türkiye'ye yansımaları içinde: (s. 149-176). İstanbul: BETA Yayıncılık.

Flavián, C., Guinalíu M. ve Gurrea, R. (2006). The Role Played by Perceived Usability, Satisfaction and Consumer Trust on Website Loyalty. Information \& Management, 43(1), 1-14. DOI: 10.1016/j.im.2005.01.002

Goodwin, M. ve Painter, J. (1996). Local Governance, the Crises of Fordism and the Changing Geographies of Regulation. Transactions of the Institute of British Geographers, 21(4), 635648. DOI: $10.2307 / 622391$

Grönlund, A. (2001). Democracy in an IT-Framed Society. Communication of the ACM, (44), 22-26. DOI: 10.1145 / 357489.357498

Güçoğlu, V. (2020). Kamu Hizmetlerinin Sunumunda Dijital Dönüşüm: Nesnelerin İnterneti Üzerine Bir İnceleme. MANAS Sosyal Araştırmalar Dergisi, 9(1), 615-628. DOI:

$10.33206 /$ mjss.538784 
Hazman, G.G. (2005). Afyonkarahisar Belediyesinde e-Belediye Uygulamaları ve Yerel Farkındalık. Afyon Kocatepe Üniversitesi İ.I.B.F. Dergisi, 7(2), 65-84. Erişim adresi: https://dergipark.org.tr/tr/pub/akuiibfd/issue/1634/20498

Heeks, R. (2001). Understanding eGovernance for Development. Institute for Development Policy and Management, 11(3), 1-27. DOI: 10.13140 / RG.2.2.14715.46882

Henden, H.B. ve Henden, R. (2005). Yerel Yönetimlerin Hizmet Sunumlarındaki Değişim ve eBelediyecilik. Elektronik Sosyal Bilimler Dergisi, 4(14), 48-66. Erişim adresi: www.esosder.com ISSN:1304-0278

Kalkışım, H. M. (2019). Yönetişim kavram ve teorisi üzerine bir değerlendirme. Parlak B. ve Doğan K.C. (Ed.), E-yönetişim: kavramsal/kuramsal çerçeve, ülke incelemeleri ve Türkiye'ye yansımaları içinde: (s. 19-32). İstanbul: BETA Yayıncılık.

Klein, M. (2019). İşletmelerin Dijital Dönüşüm Senaryoları- Kavramsal Bir Model Önerisi. Elektronik Sosyal Bilimler Dergisi, 19 (74), 997-1019. Erişim adresi: https://doi.org/10.17755/esosder.676984

Lindgren, I., van Veenstra, A. F. (2018, May). Digital government transformation: a case illustrating public e-service development as part of public sector transformation. In Proceedings of the 19th Annual International Conference on Digital Government Research: Governance in the Data Age ,1-6. DOI: 10.1145/3209281.3209302

Newman, J. (2004). Constructing Accountability: Network Governance and Managerial Agency. Public Policy and Administration, 19(4), 17-33. DOI: 10.1177/095207670401900402

Organisation for Economic Co-operation and Development (2001). Citizens as Partners: Information, Consultation and Public Participation in Policy-Making. Paris, France: OECD Publishing.

Organisation for Economic Co-operation and Development (2003). Promise and Problems of EDemocracy, Challenges of Online Citizen Engagement. OECD Publishing.

Özen, A. ve Gürel, F.N. (2020). Kamu Denetiminde Dijital Dönüşüm: Dijital İkiz Yöntemi. İzmir Sosyal Bilimler Dergisi, 2 (1), 16-23. https://dergipark.org.tr/tr/pub/izsbd/issue/52269/696209

Özer, M.A. (2017). Yönetişimden Dijital Yönetişime: Paradigma Değişiminin Teknolojik Boyutu. HakIş̧ Uluslararası Emek ve Toplum Dergisi, 6(16), 457-479. Erişim adresi: https://dergipark.org.tr/en/pub/hakisderg/issue/33300/330676

Palvia, S. C. J., Sharma, S. S. (2007). E-Government and E-Governance: Definitions/Domain Framework and Status Around the World. International Conference on E-governance, (5), 112.

Parlak, B., Doğan K.C. (2019). E-yönetişim: kuramsal bir analiz. Parlak, B., Doğan K.C. (Ed.), Eyönetişim: kavramsal/kuramsal çerçeve, ülke incelemeleri ve Türkiye'ye yansımaları içinde (s.7-18). İstanbul: BETA Yayıncılık.

Polat, R. K. (2006). E-belediyecilik kılavuzu yerel yönetim vatandaş etkileşimi. İstanbul: TASAM Yayınları.

Sæbø, Ø., Rose, J. ve Flak, L. S. (2008). The shape of eParticipation: Characterizing an emerging research area. Government information quarterly, 25(3), 400-428. DOI: 10.1016 / j.giq.2007.04.007

Saxena, K. B. C. (2005). Towards Excellence in e-Governance. International Journal of Public Sector Management, (6), 498-513. DOI: 10.1108 / 0951355051061673

Sayımer, İ., Dondurucu, Z.B. ve Küçüksaraç, B. (2019). Dijitalleşen Kentlerde Yönetişim: Marmara Bölgesi Büyükșehir Belediyeleri'nin Karşılaștırmalı E-Belediyecilik Uygulamaları. IBAD Sosyal Bilimler Dergisi, (5), 420-443. DOI: 10.21733/ibad.624340

Saylam, A. (2019). Kamu yönetiminde e-katılım. Kocaoğlu B.U. (Ed.), Kamu yönetiminde doğrudan vatandaş katılımı içinde: (s.91-115). Ankara: İmaj Yayınevi. 
Stoker, G. (1998). Governance as Theory: Five Propositions. International Social Science Journal, 50(1), 17-28. DOI: 10.1111/issj.12189

T.C. Kalkınma Bakanlığı Çalışma Grubu Raporu (2018). On Birinci Kalkınma Planı (2019-20203): EDevlet Hizmetlerinin Geliştirilmesi. Ankara.

Tekeli, İ. (1996). Yönetim Kavramı Yanısıra Yönetişim Kavramının Gelișmesinin Nedenleri Üzerine. Sosyal Demokrat Değişim, (3), 45-54.

Trajkovik, V. (2013). Yerel Yönetimler İçin Bilgi ve İletişim Teknolojileri BİT: Standartlar, İlkeler ve En İyi Uygulamalar. T.C. Marmara Belediyeler Birliği Yayını, Yayın No: 81, İstanbul.

Uzun, A. (2019). Dijital çağda e-yönetişim: konsept, pratik ve gelişim. Parlak B. ve Doğan K.C. (Ed.), E-yönetişim: kavramsal/kuramsal çerçeve, ülke incelemeleri ve Türkiye'ye yansımaları içinde: (s.33-56). İstanbul: BETA Yayıncılık.

Ünlü, U. (2016). Sosyal Belediyecilik Anlayışının e-Belediyecilik Uygulamalarına Entegre Edilmesi. Sayıştay Dergisi, (2), 63-89. http://dergi.sayistay.gov.tr

Wimmer, M.A. (2007). Ontology for an e-Participation Virtual Resource Centre. In Proceedings of the 1st international conference on Theory and Practice of Electronic Governance-ICEGOV, (7), 8998. DOI: $10.1145 / 1328057.1328079$

Yılmaz, V. (2019). Doğu Anadolu Bölgesinde e-belediyecilik hizmetlerinin yerel halk tarafından kullanım düzeylerinin değerlendirilmesi: Bitlis ve Muş Belediyesi örnekleri. Parlak B. \& Doğan K.C. (Ed.), E-yönetişim: kavramsal/kuramsal çerçeve, ülke incelemeleri ve Türkiye’ye yansımaları içinde: (s.509-532). İstanbul: BETA Yayıncılık.

Ulaştırma, Denizcilik ve Haberleşme Bakanlığı'nın Teşkilat ve Görevleri Hakkında Kanun Hükmünde Kararname. (2011, 1 Kasım). Resmi Gazete (Sayı:28102). Erişim adresi: https://www.resmigazete.gov.tr/eskiler/2011/11/20111101M1-1.htm

Yatırım Ortamının İyileștirilmesi Amacıyla Bazı Kanunlarda Değişiklik Yapılmasına Dair Kanun. (2018, 10 Mart). Resmi Gazete (Sayl:30356). Erişim adresi: https://www.resmigazete.gov.tr/eskiler/2018/03/20180310-9.htm

E-Devlet Hizmetlerinin Yürütülmesine İlişkin Usul ve Esaslar Hakkında Yönetmelik. (2016, 3 Eylül). Resmi Gazete (Sayl:29820). Erişim adresi: https://www.resmigazete.gov.tr/eskiler/2016/09/20160903-2.htm

https://www.yerelnet.org.tr/hakkimizda/, (Erişim Tarihi: 09.05.2020)

https://www.belediye.gov.tr/hakkimizda (Erişim Tarihi: 11.05.2020)

\section{Extended Abstract}

Humanity has gone through many processes from past to present, both socially and industrially. However, each of the processes laid the groundwork for the development of the other. Rapid developments, especially in the context of information and communication technologies, have accelerated the "digitalization" process, which has an impact in every field in our age. This digitalization, also known as "Industry 4.0", mainly in the private sector and production channels has shown its effect in many areas such as communication networks and management processes and continues to do so. This digital transformation dynamism experienced on a global scale necessitated change in public administration as in many other fields. Today, when concepts such as internet of things, artificial intelligence and high automation are integrated into business processes, public sector work and services have also started to be provided through various internet-based applications. Thus, while the distance between the citizen and the public administration was shortened, the way for a networked and open management structure was opened.

The governance approach, which has been used to explain business practices and processes in the private sector for a long time and expresses a departure from the traditional, rigid hierarchical and bureaucratic structure in public administration, has turned into e-governance when combined with all these developments, which is also called network governance. On the basis of the governance approach, there are "multi-stakeholder and accountable management, social cooperation, the existence of a strong civil society, openness in management, and a citizen who can actively participate in management". E-governance, in its most general definition, refers to the use of 
information and communication technologies at various levels of management to improve governance. Egovernance takes the responsibility to strengthen democracy, increase individual autonomy, and promote fair and efficient provision of services through the use of appropriate technologies. Due to these advantages in the realization of good governance, e governance is an important approach for local governments as much as central government. E-governance is expected to strengthen local democracy, especially as local governments are closer to the public. In addition, since local governments are close to the public, they are units that create the best application area for the governance approach.

While "e-government" is shown as the most obvious example of the reflection of e-governance on public administration, "e-municipalism" practices in local administrations develop within the scope of e-governance. Emunicipality is a social service platform where the provision of goods and services that municipalities are obliged to realize to local people is carried out electronically. Expected from this platform, supporting active participation of citizens in the administration, creating an information pool accessible to everyone, increasing efficiency and thus increasing citizen satisfaction. Therefore, the main purpose of e-municipal practices is to support e-governance and make it more effective. For this reason, it is important to determine to what extent local governments adopt egovernance elements and to what extent they make their applications adequate to this extent.

The aim of this study is to reveal local government policies within the scope of e-governance parameters. Study subject; "Municipal websites; Is it at a sufficient level in terms of "access to public information, online participation and consultation, online municipal services, usability and privacy / security features" that are required to ensure effective e-governance and to be a functional application? Do municipalities differ from each other in terms of the adequacy of online applications related to the listed subjects? " questions are discussed in the context and limited. Subjets discussed in the theoretical part in line with the purpose and subject of the study are "digital transformation of public administration and e-governance" and "e-governance development at the local level in Turkey". Aegean Region metropolitan and provincial municipalities were selected as the research sample. The official websites of the selected municipalities were subjected to content analysis comparatively in line with the determined criteria. While creating the criteria, analysis was carried out under the main headings of "e-municipality practices to ensure effective e-governance" and "usability and privacy / security features of e-municipality applications" and various findings were obtained.

As a result of the study, it is seen that the municipalities in the sample have a positive approach to e-governance policies and develop practices in this direction. However, it has been determined that more effective policies need to be developed in order to increase their competencies and reach the management structure envisaged by $e$ governance. 
